\title{
PENYEDIAAN PEMBANGKIT LISTRIK TENAGA SURYA BAGI RUMAH MASYARAKAT DESA LAU DAMAK
}

\author{
Budi Utomo ${ }^{1}$, Kasmir Tanjung ${ }^{2}$, Suri Mutia Siregar ${ }^{3}$ \\ ${ }^{1}$ Fakultas Kehutanan, Universitas Sumatera Utara \\ ${ }^{2}$ Fakultas Teknik, Universitas Sumatera Utara \\ ${ }^{3}$ Fakultas Psikologi, Universitas Sumatera Utara
}

budiutomo@usu.ac.id, kasmir@usu.ac.id, suri.mutia@usu.ac.id

\begin{abstract}
Abstrak
Penyediaan listrik masih menjadi tantangan bagi beberapa daerah di Indonesia, salah satunya adalah Desa Lau Damak. Secara administrasi, Desa ini berjarak cukup dekat dengan pusat ibukota provinsi Sumatera Utara (Medan), yakni $80 \mathrm{~km}$. Namun pada kenyataannya hingga kini salah satu dusun di wilayah ini masih belum tersentuh listrik. Sulitnya akses menuju ke desa ini, menyebabkan Dusun Tg. Beringin yang terletak di Desa Lau Damak dihuni oleh 15 kepala keluarga. Penerangan sebagai kebutuhan dasar harus dipenuhi dari lampu minyak (sentir). Beberapa warga yang cukup beruntung, dapat membeli genset yang hanya beroperasi pada pukul 18.3021.00 wib. Setelah itu penerangan dilanjutkan menggunakan lampu minyak. Munculnya Tim Pelaksana pengabdian pada masyarakat Program Kemitraan Masyarakat (PPM PKM) USU ke wilayah mitra ini memberikan harapan baru bagi masyarakat. Tim segera menganalisis kebutuhan energi untuk menerangi kampung ini. Untuk dapat menerangi sekitar 15 rumah yang letaknya berdekatan satu dengan lainnya Tim segera membuat 2 pos PLTS yang ditempatkan pada rumah-rumah warga. Selanjutnya Tim PPM membangun PLTS berkekuatan 800 watt. Kini warga Dusun Tg Beringin dapat berbahagia karena dapat menikmati energi penerangan sepanjang waktu 24 jam tanpa harus mengeluarkan biaya. Warga dapat menikmati siaran televisi serta dapat mengisi daya handphone di kampung ini.
\end{abstract}

Kata Kunci : Listrik, Pembangkit Listrik Tenaga Surya, Penerangan.

\section{PENDAHULUAN}

Desa Lau Damak merupakan salah satu desa yang berada di Kecamatan Bahorok, Kabupaten Langkat, Sumatera Utara yang wilayahnya berbatasan langsung dengan Taman Nasional Gunung Leuser dan ditetapkan sebagai kawasan penyangga taman nasional. Desa ini berbatasan langsung dengan wilayah hutan pegunungan yang berisikan gunung kapur. Desa Lau Damak memiliki 7 dusun, di antaranya Dusun 1 (Lau Damak), Dusun 2 (Namo Cengkeh), Dusun 3 (Selayang), Dusun 4 (Sukamulia), Dusun 5 (Tanjung Naman), Dusun 6
(Tg. Beringin), dan Dusun 7 (Ujung Gorap) dengan jumlah kepala keluarga sebanyak 560. Di Desa ini, masih terdapat beberapa tempat yang tidak menikmati manfaat adanya listrik secara langsung, salah satunya adalah dusun Tg. Beringin.

Dusun Tg. Beringin memiliki bagian wilayah yang bernama Tanjung Bringin. Wilayah Tanjung Bringin memiliki jumlah kepala keluarga sebanyak 7. Tanjung Beringin berbatasan langsung dengan kawasan hutan gunung kapur, serta terletak pada wilayah yang cukup terpencil sehingga wilayah ini berada jauh dari sumber listrik instalasi PLN.

$$
\text { Teknologi Tepat Guna }
$$


Mayoritas penduduk Tanjung Bringin bermata pencarian sebagai petani dan usaha kecil-kecilan. Sementara itu, warga Tanjung Bringin sudah pernah mengajukan permintaan masuknya listrik ke pihak yang terkait, namun pemasangan instalasi listrik tidak kunjung terealisasi karena alasan tidak ekonomis.

Listrik sudah masuk ke Indonesia sejak akhir abad ke-19. Rumah yang dulunya hanya diterangi lampu minyak setelah matahari terbenam kini tampak lebih benderang. Namun pada kenyataannya hingga kini tidak seluruh masyarakat Indonesia menikmati fasilitas listrik. Dari 250 juta penduduk Indonesia, hanya 190 juta penduduk yang merasakan manfaat dari listrik yang dikelola oleh PLN. Kondisi dan tantangan kelistrikan Indonesia di masa kini, masih banyak yang belum menikmati listrik yang pada umumnya bertempat tinggal di daerah pinggiran atau pesisir, namun ada pula yang lokasinya tidak jauh dari kota. Desa Lau Damak secara administrasi merupakan salah satu desa yang berjarak cukup dekat dengan pusat ibukota propinsi (Kota Medan) yakni berjarak $80 \mathrm{~km}$, atau hanya 55 $\mathrm{km}$ dari kota Binjai. Namun pada kenyataannya hingga kini salah satu dusun di wilayah ini belum tersentuh listrik.

Sasaran mitra dalam program PKM ini adalah Kelompok Masyarakat yang beranggotakan petani/pekebun dan tinggal di Dusun Tg. Beringin. Anggota kelompok tani di wilayah ini umumnya bermata pencaharian sebagai petani atau pekebun. Secara umum masyarakat berkebun kelapa sawit dengan kepemilikan rata-rata 0.5-1 $\mathrm{Ha} / \mathrm{KK}$. Umumnya anggota kelompok masyarakat ini cenderung membuat rumah yang dekat dengan tempat usahanya tersebut. Oleh karena itu tidak heran jika letak rumah warga pekebun ini berjauhan satu dengan lainnya. Sebaran letak rumah yang berjauhan ini menyebabkan peluang pembangunan instalasi jaringan listrik PLN tidak lagi efisien. Oleh karena itu hingga kini rumah-rumah warga ini belum terlayani aliran listrik.

Keterbatasan perekonomian menyebabkan warga sebagai anggota kelompok tani ini harus rela hidup tanpa fasilitas listrik. Sehari-hari penerangan pada malam hari diperoleh dari lampu minyak. Keterbatasan keuangan warga untuk membeli bahan bakar menyebabkan warga yang memiliki genset pribadi hanya mampu menyalakan listik hingga pukul 21.00 wib, yang dilanjutkan dengan penerangan lampu minyak (sentir) hingga pagi hari.

Menurut warga yang menjadi mitra pada rencana kegiatan PPM ini (ketua kelompok tani) warga telah mengeluhkan kondisi ini pada pemerintah desa setempat, namun hingga kini keinginan masyarakat ini belum terlayani mengingat keterbatasan anggaran yang tersedia. Ketiadaan ilmu pengetahuan menyebabkan hingga kini masyarakat terus hidup tanpa penerangan listrik.

Mitra pada program PPM PKM ini direncanakan adalah kelompok masyarakat yang tinggal di wilayah batas hutan TNGL yakni Dusun Tg. Beringin, Desa Lau Damak, Kabupaten Langkat. Saat Tim PPM USU berkunjung ke lokasi diterima oleh masyarakat dan Sekretaris Desa yang tinggal berdekatan dengan dusun ini. Dalam musyawarah bersama masyarakat, Tim mencoba menggali permasalahan utama yang dihadapi masyarakat. Berdasarkan hasil musyawarah didapati bahwa Dusun Tg. Beringin yang masih menghadapi masalah listrik. Warga dusun ini yang merupakan anggota kelompok tani mitra yang tinggal menyebar pada areal usaha kebunnya belum dapat menikmati layanan listrik PLN. Kebutuhan listrik dipenuhi dari lampu minyak (sentir). Jauhnya jarak antar warga pekebun menyebabkan PLN tidak mampu menyediakan jaringan listrik bagi warga ini karena tidak lagi efisien bagi PLN.

Walau demikian cukup banyak warga yang tinggal tanpa fasilitas listrik ini. Tidak kurang dari 18 rumah warga di wilayah ini masih menggunakan penerangan lampu minyak. Ketiadaan penerangan umum tak pelak juga menyebabkan kerawanan keamanan. Oleh karena itu, hingga kini warga mengantisipasinya dengan cara tidak keluar/pulang terlalu malam untuk mengurangi resiko munculnya tindak kriminal perampokan di jalan. Listrik sebagai kebutuhan dasar masyarakat kini menjadi persoalan prioritas mitra yang perlu diselesaikan. Masyarakat telah seringkali mengeluhkan masalah listrik ini kepada pemerintah desa dan kecamatan. Keterbatasan anggaran dan rendahnya PAD lagi-lagi menjadi alasan pemerintah setempat sehingga pembangunan jaringan ini tak kunjung dilakukan. Diperlukan dukungan ipteks perguruan tinggi untuk percepatan peningkatan kesejahteraan masyarakat di wilayah ini. 
Munculnya Tim Pelaksana PPM PKM USU ke Desa Lau Damak ini memberikan harapan baru bagi masyarakat. Masyarakat secara antusias mengeluhkan kondisi ini dan berharap tim pelaksana PPM USU dapat membantu mengatasi permasalahan warga ini. Hasil pemantauan Tim Pelaksana PPM pada beberapa rumah warga membuktikan keluhan warga ini. Tim PPM mencoba memberikan solusi pemecahan masalah masyarakat tersebut melalui program PkM yang diusulkan. Ketersediaan dana yang bersumber dari dana Non PNBP USU ini harus mampu membantu mengatasi permasalahan warga melalui iptek perguruan tinggi.

\section{METODE}

Program PPM PKM yang diusulkan ke LPPM dana Non PNBP USU anggaran tahun 2020 direncanakan akan dilaksanakan di wilayah Dusun Tg. Beringin Desa Lau Damak Kecamatan Bahorok Kabupaten Langkat. Kegiatan direncanakan berlangsung selama 6 bulan sejak awal kegiatan hingga penyerahan laporan kegiatan.

Untuk mendukung realisasi keberhasilan program PPM PKM yang ditawarkan maka prosedur penyelesaian masalah dilakukan sesuai urutan sebagai berikut: 1) Identifikasi permasalahan; 2) Pemilihan alternatif Penyelesaian Masalah dan Metode Analisis; 3) Analisis ketersediaan bahan baku pembentuk produk iptek; 4) Analisis kemampuan bengkel/workshop membuat sistem penerangan mandiri; 5) Perancangan alat; 5) Instalasi peralatan; 6) Pengawasan dan pemeliharaan, yang meliputi: a. Pembelajaran tentang sistem bekerja sistem peralatan PLTS dan teknik pemeliharaannya hingga supplier suku cadang jika sistem mengalami kerusakan; b Masing-masing mitra kelompok tani membentuk struktur yang bertanggung jawab terhadap kelangsungan operasional PLTS yang dibangun berikut instalasinya; c. Kelompok PLTS ini akan dikutip sejumlah dana yang akan digunakan untuk pemeliharaan sistem alat baik kebutuhan penggantian suku cadang penerangan rumah tangga.

Pembangunan Pembangkit Listrik Tenaga Surya direncanakan akan dimulai dengan membangun pos untuk memanen energi matahari yang berkekuatan 400 watt peak. Energi matahari yang dipanen akan disimpan dalam baterai berkekuatan $120 \mathrm{AH} 12 \mathrm{~V}$. Baterai ini berdasarkan hasil perhitungan akan dapat melayani penerangan untuk 6-8 rumah yang masing-masingnya memiliki 4 lampu 5-9 watt. Selanjutnya, tim juga akan menginstalkan power inverter berkekuatan 2000 watt untuk memenuhi kebutuhan mengisi daya handphone dan televisi.

Setelah kegiatan program PPM PKM selesai dilaksanakan, maka dilakukan evaluasi untuk mengetahui sejauh mana kegiatan PPM memberi dampak bagi masyarakat berupa: animo masyarakat untuk mengikuti kegiatan, motivasi masyarakat untuk mempelajari program iptek yang disampaikan, kepuasan mitra pada produk program PPM yang dilaksanakan, dan tingkat keberhasilan program PPM yang dilaksanakan. Untuk mengusahakan keberlanjutan program setelah kegiatan PPM PKM selesai dilaksanakan, maka Tim pelaksana PPM melakukan pelatihan tentang tata cara instalasi PLTS secara sederhana pada masyarakat. Selain itu tim juga memaparkan fungsi masing-masing alat serta menyampaikan sumber suku cadang dapat diperoleh bagi masyarakat. Hal ini merupakan hal penting mengingat PLTS dianggap merupakan teknologi baru dan rumit bagi masyarakat. Dengan pengajaran tersebut diharapkan masyarakat yang belum mendapatkan fasilitas penerangan karena keterbatasan biaya dari Tim PPM USU kali ini akan dapat membuat instalasi sendiri sehingga permasalahan kebutuhan energi listrik bagi penerangan warga dapat teratasi di wilayah ini.

USU memiliki sumberdaya yang cukup untuk mengatasi permasalahan yang dihadapi masyarakat desa di wilayah sasaran. Hal ini ditunjukkan dengan antusias tim pelaksana PPM yang berasal dari Fakultas Kehutanan dan Fakultas Teknik. Kedua fakultas memiliki tenaga ahli yang berkualitas untuk mewujudkan sistem penerangan PLTS ini. Kedua fakultas didukung oleh laboratorium yang lengkap sehingga diyakini mampu menciptakan sistem peralatan dimaksud yang berbiaya ekonomis demi kemajuan perekonomian di wilayah sasaran. Alat yang diciptakan diharapkan bisa menjadi model bagi pembuatan alat-alat di wilayah lain yang menghadapi masalah yang sama. Oleh karena itu kegiatan pengabdian pada masyarakat PKM yang bersumber dari dana Kemenristek Dikti dianggap mampu dijalankan dengan baik sesuai harapan (USU, 2019). 


\section{HASIL DAN PEMBAHASAN}

Melalui kegiatan pengabdian kepada masyarakat (PPM) mono tahun regular Tim PPM USU membangun sarana pembangkit listrik tenaga surya (PLTS) bagi warga Dusun Tg Beringin Desa Lau Damak Kecamatan Bohorok Kabupaten Langkat. Wilayah yang sangat terisolir ini berbatasan dengan kawasan Taman Nasional Gunung Leuser (TNGL) dengan akses yang buruk hanya dapat dilalui kenderaan jip 4 x 4 . Kesulitan ini diperparah dengan jauhnya jarak wilayah ini dengan dusun lainnya mengakibatkan akses ke dusun ini sangat sulit. Tidak kurang dari 18 kepala keluarga tinggal di dusun ini. Menurut warga setempat Erdison Ginting dahulu lebih banyak lagi warga yang tinggal di dusun ini, namun karena ketiadaan listrik mengakibatkan warga pindah ke dusun lainnya yang telah mendapatkan fasilitas listrik. Warga menuturkan mereka sejak lama tinggal di dusun ini karena ingin tinggal tidak jauh dari kebun tempat usahanya. Akses yang buruk mengakibatkan sulitnya keluar masuk wilayah jika harus tinggal di luar dari dusun ini.

Warga telah lama mengeluhkan hal ini melalui Kepala Desa Lau Damak, namun hingga kini belum ada tanda-tanda bahwa wilayah ini akan disentuh oleh PLN. Masuknya Tim pelaksana PPM yang menjanjikan akan mencari solusi beberapa waktu yang lalu memberikan angin segar bagi warga.

Pada akhir Juli 2020 yang lalu Tim membawa solusi berupa penerangan berbasis PLTS untuk menerangi rumah-rumah warga. Tim melakukan identifikasi penempatan peralatan PLTS. Dari hasil analisis PLTS menempatkan 2 pos yang masingmasing berkekuatan 400 watt peak. Selanjutnya energi matahari yang dipanen dari atap rumah akan disimpan dalam 2 buah baterai berkekuatan $120 \mathrm{AH}$ $12 \mathrm{~V}$. Baterai ini berdasarkan hasil perhitungan akan dapat melayani penerangan untuk 6-8 rumah yang masing-masingnya akan diisi 4 lampu 5-9 watt. Selanjutnya untuk kebutuhan pengecasan HP dan televisi, diinstallkan power inverter berkekuatan 2000 watt pada masing-masing pos. dengan demikian seluruh daya yang terpasang diyakini akan mampu menyediakan penerangan bagi 12-15 rumah warga yang ada di dusun ini.

Kini Dusun Tg Beringin yang tidak pernah menikmati sinar lampu di malam hari mampu berbahagia menikmati fasilitas listrik ini.
Sebelumnya warga harus menumpang ke dusun terdekat untuk sekedar mengecas telephone genggam, kini hal ini tak lagi perlu karena warga telah dapat melakukan pengecahan HP kapan saja. Demikian pula warga kini dapat menikmati fasilitas informasi dari televisi.

Kepala Desa Lau Damak Ngemat Ginting menyampaikan ucapan terima kasih kepada Tim pelaksana PPM USU atas fasilitas yang diberikan bagi warganya itu. Beliau juga menyatakan bahwa sejak lama pihaknya terus mendesak PLN untuk memasukkan listrik ke daerah ini namun tidak juga kunjung terealisasi. Masuknya Tim USU telah memberikan solusi yang selama ini warga inginkan kendati besaran watt yang dipasok tidak sebesar listrik PLN.
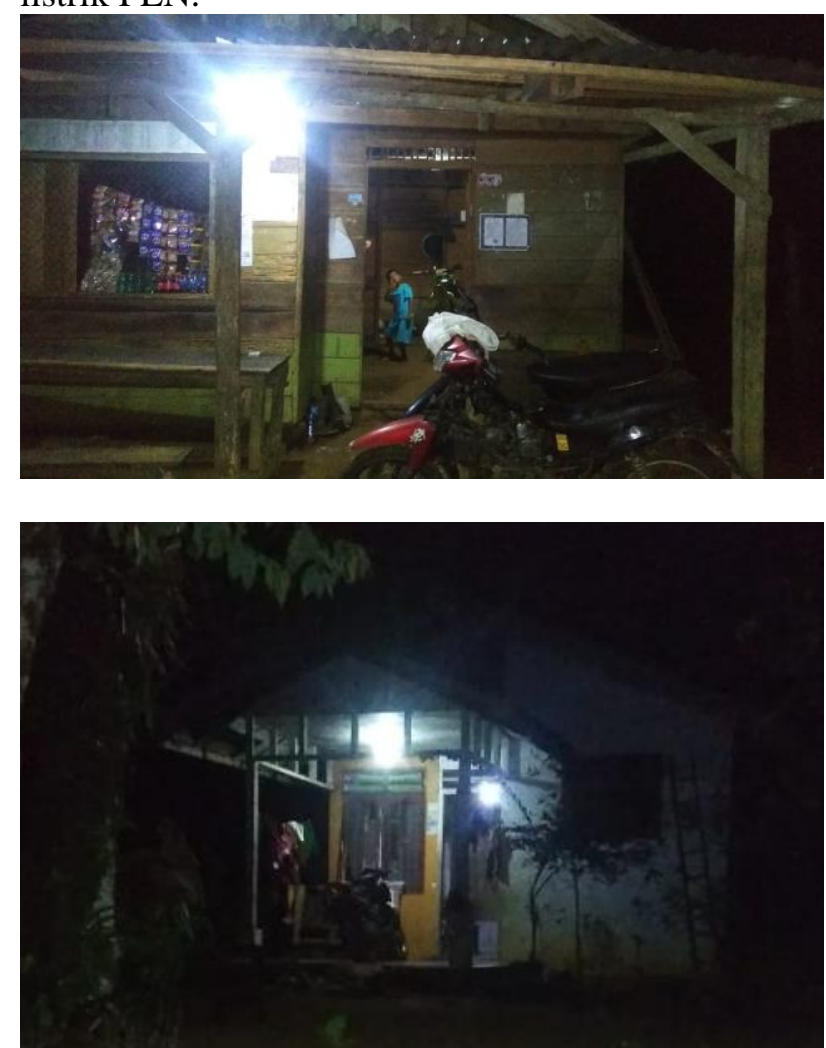

Gambar. Rumah-rumah di Dusun Tg Beringin Desa Lau Damak yang telah teraliri listrik PLTS di malam hari

\section{KESIMPULAN}

Penggunaan solar panel 800 WP yang disimpan dalam 2 stasiun menggunakan tenaga baterai 2 x $120 \mathrm{AH}$ telah dapat menyediakan listrik yang mencukupi untuk 15 rumah yang ada di dusun

$$
\text { Teknologi Tepat Guna }
$$


Tg Beringin Desa Lau Damak Kecamatan Bohorok Kabupaten Langkat. Setelah kegiatan selesai dilaksanakan, masyarakat diminta untuk melakukan urunan untuk menyediakan biaya pemeliharaan maupun perbaikan pembangkit listrik tenaga surya. Tim Pengabdi berharap, kegiatan serupa dapat dilaksanakan di daerah-daerah lain yang belum tersentuh listrik di wilayah Sumatera Utara.

\section{UCAPAN TERIMAKASIH}

Tim Pengabdian Desa Pekan Sawah mengucapkan terimakasih kepada Lembaga Pengabdian/Pelayanan Kepada Masyarakat Universitas Sumatera Utara (LPPM-USU) yang telah memberikan kesempatan berupa hibah dana untuk melaksanakan seluruh rangkaian pengabdian. Selain itu, Tim juga memberikan penghargaan kepada seluruh perangkat Desa Lau Damak yang telah memberikan dukungan selama kegiatan pengabdian berlangsung.

\section{REFERENSI}

Akhmad, K. 2011. Pembangkit Listrik Tenaga Surya dan Penerapannya Untuk Daerah Terpencil, Jurnal Dinamika Rekayasa 1(1): 28- 33

Arfianto AEW dan Balahmar ARU. 2014. Pemberdayaan Masyarakat dalam Pembangunan Ekonomi Desa. JKMP 2:1 1-93.

Badollahi A. 2013. Menuju Pembangunan Desa 2015-2019. Arah Kebijakan Nasional dan Strategi Pengembangan Wilayah Pedesaan. http://media.kompasiana.com/ buku/2014/ 10/31/menuju-pembangunan-desa-2015-2019684013.html
[BPS] Badan Pusat Statistik. 2015. Kabupaten Langkat dalam Angka tahun 2018. Seri Publikasi Tahunan BPS Kabupaten Langkat Provinsi Sumatera Utara.

[LPPM USU] Lembaga pengabdian pada masyarakat. 2016. Program kegiatan. http://usu.ac.id/id/ (diakses pada 05 April 2016).

Rahayuningtyas, A., Kuala, S.I., dan Apriyanto, F. 2014. Studi Perencanaan Sistem Pembangkit Listrik Tenaga Surya (Plts) Skala Rumah Sederhana Di Daerah Pedesaan Sebagai Pembangkit Listrik Alternatif Untuk Mendukung Program Ramah Lingkungan Dan Energi Terbarukan, Prosiding SnaPP 2014 Sains, Teknologi, dan Kesehatan pp. 223-230.

Ramadhan A.I., Diniardi E, Mukti S. H. 2016. Analisis Desain Sistem Pembangkit Listrik Tenaga Surya Kapasitas 50 WP. Teknik 37(2), 2016, 59-63.

Salman R. 2013. Analisis Perencanaan Penggunaan Sistem Pembangkit Listrik Tenaga Surya (PLTS) untuk Perumahan (Solar Home System). Jurnal Smartek, 4(3) 46-51.

Subandi dan Hani S. 2015. Pembangkit Listrik Energi Matahari Sebagai Penggerak Pompa Air Dengan Menggunakan Solar Cell, Jurnal Teknologi Technoscientia 7(2): 157-163

[USU]. Universitas Sumatera Utara. 2016. Fasilitas dan sumber. http://lppmusu.ac.id/id/ (diakses pada 05 April 2016). 